\title{
Analisis Penerapan Code Splitting Library React pada Aplikasi Penjualan Mebel Berbasis Website
}

\author{
http://dx.doi.org/10.28932/jutisi.v7i2.3493 \\ Riwayat Artikel \\ Received: 04 Maret 2021 | Final Revision: 29 Juni 2021 | Accepted: 06 Juli 2021 \\ Daniel Tanudjaja ${ }^{\bowtie \# 1}$, Radius Tanone ${ }^{* 2}$ \\ \#Jurusan Teknik Informatika, Universitas Kristen Satya Wacana \\ Jl. Diponegoro no. 52-60, Kota Salatiga \\ ${ }^{1}$ daniel.tndjegmail.com \\ *Jurusan Teknik Informatika, Universitas Kristen Satya Wacana \\ Jl. Diponegoro no. 52-60, Kota Salatiga \\ ${ }^{2}$ radius.tanonedstaff.uksw.edu
}

\begin{abstract}
Mebel Murah is a shop that sells furniture products located in Semarang, Central Java, Indonesia. Due to Covid-19, the sales revenue have decreased due to limited access for buyers. Therefore, an innovation is needed to overcome this, namely by creating a website that can support especially the marketing and sales of furniture products to the public. The aims of this research is to focus on testing the rendering speed of components through the React Profiler to analyze the comparison of component rendering times on the client side of the code breaking features of the React library. The result of this research is to produce a website by utilizing the code splitting feature to display information content related to products sold by Mebel Murah stores.
\end{abstract}

Keywords — Code Splitting; Furniture; Online Shopping; React; Reusable Components.

\section{Pendahuluan}

Toko Mebel Murah adalah toko yang menjual produk mebel yang berlokasi di Semarang, Jawa Tengah. Berdasarkan hasil wawancara dengan salah satu pelaku Usaha Mikro Kecil Menengah (UMKM) yang bidang usahanya terdampak Covid-19 yaitu pemilik Toko Mebel Murah menyatakan bahwa omzet penjualan dan jumlah pembeli produk mebel mengalami penurunan sejak adanya pandemi Covid-19. Penurunan itu disebabkan oleh keterbatasan akses pembeli ke Toko Mebel Murah dikarenakan adanya Covid-19 dan area pemasaran hanya di Kota Semarang dan sekitarnya. Oleh karena itu, Toko Mebel Murah ingin menerapkan penggunaan aplikasi website dalam kegiatan jual beli mebel.

Proses transaksi di Toko Mebel Murah biasanya dilakukan dengan pembeli yang datang langsung ke toko untuk memilih produk yang tersedia di toko. Dikarenakan pandemi Covid-19, tingkat kunjungan pembeli ke toko semakin menurun. Untuk mengatasi masalah tersebut diperlukan aplikasi yang dapat mempermudah transaksi antara penjual dan pembeli, membantu penjual dalam memberikan informasi terkait produk mebel yang tersedia, dan memberikan informasi terkait status pemesanan barang yang dibeli oleh.

Berdasarkan permasalahan yang dialami pembeli ataupun penjual maka dibangun sistem berupa website penjualan produk mebel yang dapat mengakomodasi segala kebutuhan user, seperti: memilih dan melakukan pembelian secara online terhadap produk mebel dan fitur notifikasi email bagi user dapat mengetahui status pesanan. Untuk membangun website yang memiliki fitur yang kompleks dibutuhkan teknologi yang mendukung proses pengembangan website. Oleh karena itu, dalam pengembangan sistem digunakan teknologi MongoDB, Express, React, dan Node.js untuk pembuatan website penjualan Toko Mebel Murah.

Pengembangan user interface dari website sering dilakukan dengan menulis kode berulang-ulang dengan pola yang sama. Dengan hal itu membuat kerugian bagi proses pengembangan, yaitu waktu yang diperlukan menjadi lebih lama. Berdasarkan sebuah penelitian disimpulkan bahwa rata-rata $48 \%$ dari ukuran file dari kode aplikasi berasal dari user interface. Semakin besar ukuran file yang perlu diproses oleh browser maka akan semakin membebani waktu rendering di sisi klien [1]. 
Dalam proses pengembangan user interface website, dimanfaatkan library React. React merupakan library dari JavaScript yang digunakan untuk membangun user interface yang sudah mendukung reusable component. Reusable component dapat mengurangi penulisan kode yang repetitif dengan pola yang sama. Sehingga, pembuatan aplikasi menjadi lebih cepat dan terstruktur [2].

Rumusan masalah dari penelitian ini yaitu, bagaimana efektivitas penggunaan code splitting terhadap rendering komponen di sisi klien. Adapun tujuan dari penelitian ini adalah mengetahui efektivitas kecepatan rendering komponen dengan menggunakan fitur code splitting terhadap kecepatan rendering tanpa menggunakan fitur code splitting. Manfaat dari penelitian ini adalah diharapkan menghasilkan sistem yang memiliki performa yang baik sehingga dapat membantu proses penjualan produk mebel kepada pembeli. Batasan masalah dari penelitian ini adalah pengembangan front-end dari website menggunakan library React dan pengujian kecepatan rendering komponen menggunakan React profiler yang terdapat dalam React Developer Tools.

Pada penelitian terdahulu pernah mengangkat topik serupa dengan penelitian ini sehingga dapat dijadikan acuan dalam pelaksanaan penelitian ini. Penelitian pertama dengan judul "End-to-end E-commerce Web Application, a Modern Approach using MongoDB, Express, React, and Node.js (MERN) stack" yang menerapkan penggunaan dari setiap teknologi yang digunakan yaitu MongoDB, Express, React, dan Node.js. Pada penelitian ini, website yang dikembangkan memiliki fitur yang kompleks sehingga konsep reusable component digunakan untuk mengurangi waktu pengembangan front-end, desain aplikasi lebih konsisten, dan memudahkan maintenance kode ke depannya. Hasil dari penelitian berupa website penjualan buku berbasis website yang bertujuan memperluas target pasar dari toko buku dan mempermudah proses transaksi pembelian buku [3].

Penelitian selanjutnya berjudul "Optimizing the Critical Rendering Path for Decreased Website Loading Time" membahas tentang bagaimana mengurangi waktu rendering sebuah website di sisi klien. Pada penelitian ini ditemukan bahwa faktor-faktor yang mempengaruhi kecepatan rendering yaitu kecepatan koneksi internet, ukuran file (HTML, CSS, dan JS), urutan dalam rendering konten, dan client browser. Peneliti menggunakan beberapa strategi yang digunakan untuk mengurangi loading time, antara lain: mengurangi jumlah request dari client ke server, minify dan compress resources, mengurangi ukuran file gambar yang diupload oleh klien, dan caching data. Tujuan dari penelitian ini adalah menganalisis penerapan berbagai strategi untuk mengurangi loading time sebuah website. Hasil dari penelitian yaitu strategi-strategi yang digunakan terbukti mengurangi waktu loading dari sebuah website [4].

Menurut penelitian yang berjudul "Present Day Web-Development using React.js" didapatkan simpulan bahwa React adalah library yang memiliki performa yang cepat dalam rendering konten ke sisi klien. Hal tersebut disebabkan React memanfaatkan Virtual Document Object Model (VDOM) untuk membandingkan perubahan data yang terjadi pada Document Object Model (DOM) tree dengan DOM pada browser. React hanya akan melakukan rendering ulang terhadap komponen yang mengalami perubahan [5].

Berdasarkan penelitian-penelitian yang telah dipaparkan di atas, penelitian ini berfokus menguji strategi code splitting dengan membandingkan waktu rendering komponen. Pengujian dilakukan dengan menggunakan React Profiler. React Profiler merupakan tools yang berfungsi mengidentifikasi performa website dalam menampilkan konten.

Tingkat rendering website yang lambat dapat mempengaruhi user experience dalam mengunjungi website. Hal itu didukung oleh penelitian yang menunjukkan bahwa $53 \%$ pengguna akan meninggalkan website yang memiliki rendering time di atas 3 detik [6]. Sehingga, berdasarkan penelitian tersebut dapat disimpulkan bahwa batas waktu yang wajar dalam rendering konten website adalah 3 detik.

Pengembangan aplikasi menggunakan arsitektur MongoDB, Express, React, dan Node.js (MERN). MongoDB akan digunakan sebagai database, Express digunakan sebagai back-end framework, React digunakan sebagai front-end library, dan Node.js berperan sebagai environment untuk menjalankan JavaScript di sisi server.

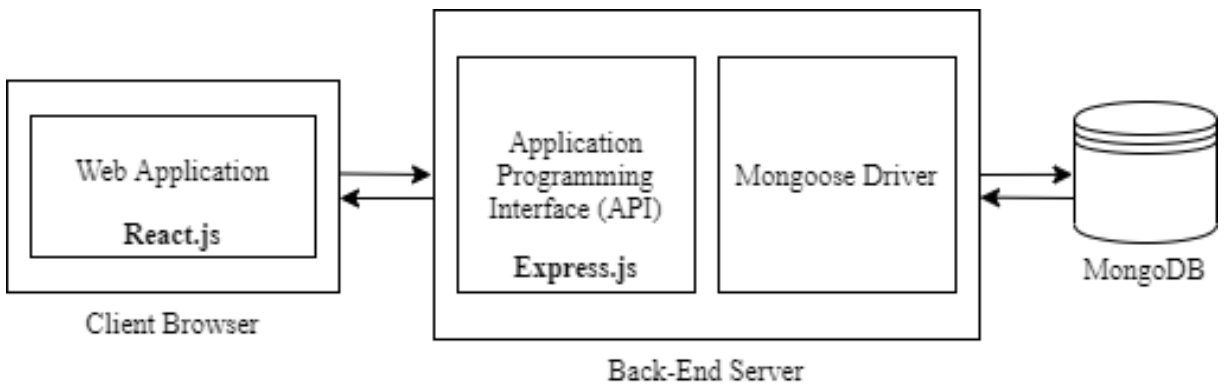

Gambar 1. Arsitektur Aplikasi 
Pada gambar 1, menggambarkan arsitektur aplikasi menggunakan MERN. Langkah pertama adalah membuat API dengan menggunakan Express, dilanjutkan konfigurasi koneksi ke MongoDB menggunakan Mongoose driver dan membuat skema dan model yang diperlukan. Ketika back-end server sudah selesai dibangun, client melakukan HTTP request ke server melalui website yang dibangun menggunakan library React dan server akan mengirimkan file yang dibutuhkan untuk di proses oleh browser [3].

React merupakan library JavaScript yang bersifat open-source yang digunakan untuk membangun interfaces yang menerapkan Single Page Applications (SPA) [7]. Keuntungan penggunaan React adalah penerapan reusable component sehingga kode yang dibangun akan menjadi lebih terstruktur, mudah dikelola dan dapat mempercepat proses pengembangan. Pembuatan komponen React dapat dilakukan dengan 2 cara, yaitu dengan menggunakan functions atau class. Secara umum, developer disarankan untuk menggunakan functions dikarenakan penulisan kode menjadi lebih efisien [8].

React mendukung Virtual Document Object Model (VDOM) [9]. VDOM adalah suatu konsep untuk merepresentasikan struktur dari suatu dokumen HTML dan bagaimana dokumen HTML dapat diakses serta dimodifikasi [10]. VDOM menyimpan representasi dari user interface di dalam memori dan disinkronkan dengan DOM pada browser oleh library seperti ReactDOM. Jadi, ketika ada update data pada state yang akan ditampilkan pada komponen, VDOM akan mencari perbedaan struktur pada DOM di browser. Proses ini disebut dengan DOM diffing atau reconciliation of state and view [5]. Dengan menggunakan React, semakin berkembangnya aplikasi maka ukuran file yang dihasilkan akan semakin besar. Hal itu akan membuat kecepatan rendering di sisi klien akan lambat. Untuk menghindari masalah ukuran file yang besar, React memiliki fitur code splitting yang bekerja dengan memecah file yang akan di proses untuk ditampilkan di browser. Code splitting akan melakukan lazy-load yang memuat komponen website yang sedang dibutuhkan oleh pengguna saja [11]. Dengan adanya code splitting diharapkan menjadi salah satu strategi dalam meningkatkan performa website.

\section{METODE PENELITIAN}

Dalam penelitian ini menggunakan metode penelitian Research and Development (RnD). Metode penelitian RnD merupakan tahapan dalam menghasilkan sebuah sistem yang berdasarkan kebutuhan pengguna [12]. Langkah-langkah penelitian dapat dilihat pada Gambar 2.

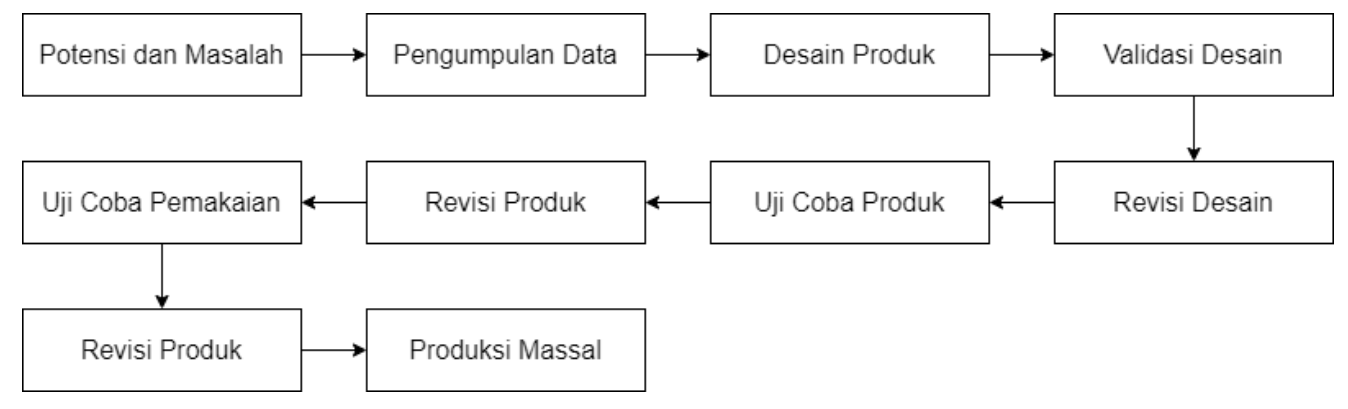

Gambar 2. Tahapan Penelitian

Pada penelitian ini tahapan penelitian dilakukan sampai pada tahap revisi produk dan tidak dilakukan sampai pada tahap produksi masal. Tahapan penelitian pada Gambar 2 dapat dijelaskan sebagai berikut:

1. Tahap pertama adalah potensi dan masalah. Dalam tahap ini dilakukan identifikasi permasalahan berdasarkan hasil wawancara dengan pemilik Toko Mebel Murah. Permasalahan yang ditemukan yaitu menurunnya omzet toko sehingga diperlukan sistem yang dapat mempermudah proses transaksi.

2. Tahap kedua adalah pengumpulan data. Pada tahapan ini dilakukan pengumpulan data yang akan digunakan untuk pembuatan sistem. Data yang diperlukan nama dan jumlah karyawan, data barang, harga barang, jumlah barang, dan proses bisnis. Data tersebut diperoleh dengan metode wawancara dengan pemilik Toko Mebel Murah.

3. Tahap ketiga adalah desain produk. Pada langkah ini, peneliti membuat desain produk dalam bentuk diagram UML.

4. Tahap keempat adalah validasi desain. Pada tahapan ini dilakukan penilaian terhadap desain produk dengan kebutuhan.

5. Tahap kelima adalah revisi desain. Pada tahap ini, peneliti melakukan revisi atas desain produk yang telah dibuat sebelumnya sesuai dengan kebutuhan.

6. Tahap keenam adalah uji coba produk. Pada tahapan ini dilakukan pengujian oleh developer untuk menemukan bug yang terdapat dalam sistem untuk diperbaiki. 
7. Tahap ketujuh adalah revisi produk. Dalam tahap ini dilakukan perbaikan pada sistem. Hasil akhir dari revisi produk merupakan produk yang diuji coba.

8. Tahap kedelapan adalah uji coba pemakaian. Pada tahapan ini, user melakukan pengujian beta terhadap fungsionalitas dari sistem.

9. Tahap kesembilan adalah revisi produk. Jika dalam tahap uji coba pemakaian ditemukan bug pada fungsionalitas website oleh pengguna, maka sistem akan direvisi kembali oleh developer.

10. Tahap kesepuluh adalah produksi masal. Pada tahapan ini sistem yang dihasilkan sudah bisa digunakan oleh pengguna jika sistem yang dibuat lulus dari tahap pengujian oleh developer dan user.

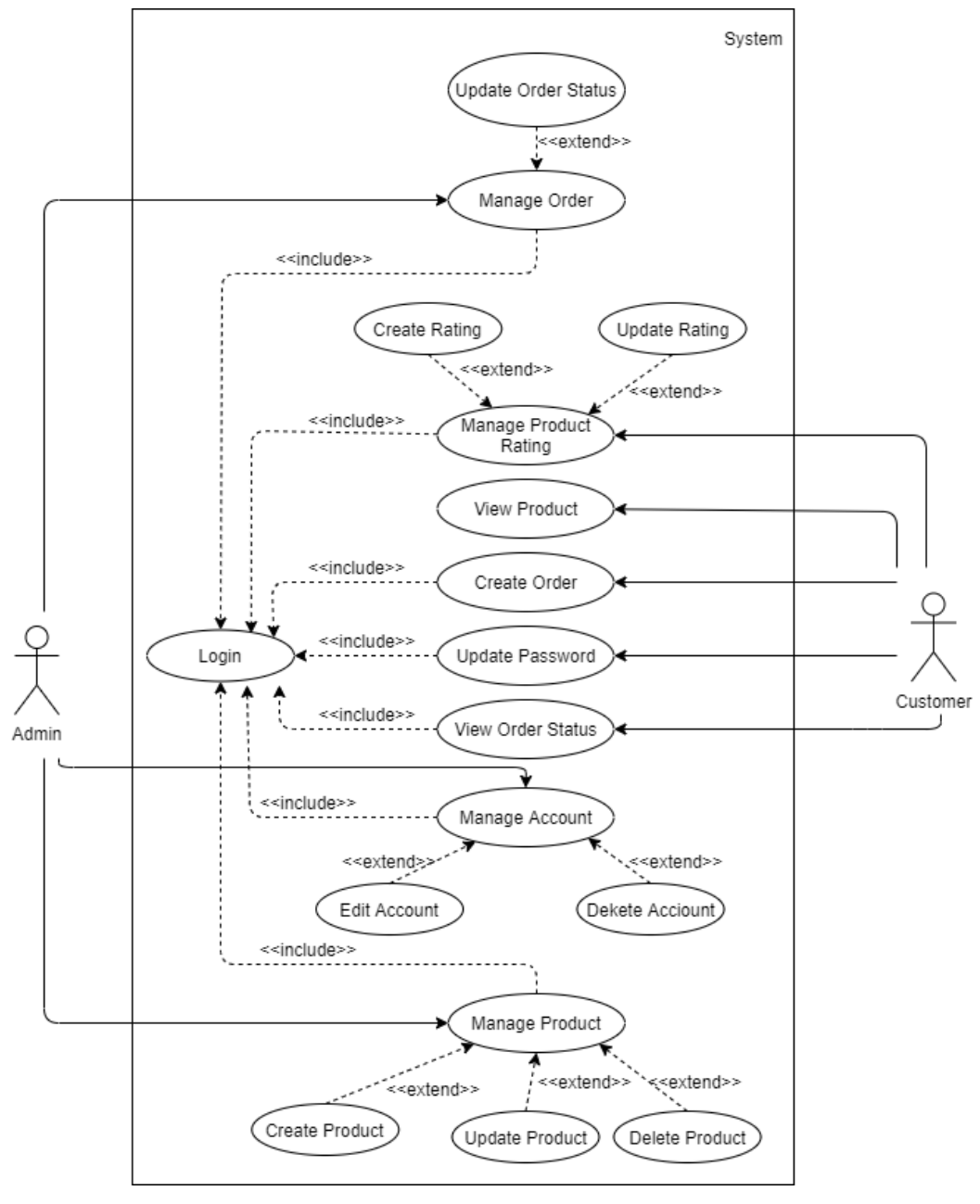

Gambar 3. Use Case Diagram

Pada Gambar 3 merupakan desain use case sistem Toko Mebel Murah. Terdapat 2 aktor dalam sistem ini yaitu admin dan customer. Kedua aktor memiliki hak akses yang berbeda-beda untuk setiap fungsi yang ada dalam sistem. Admin dapat melakukan menginput atau update produk yang akan dijual, mengelola akun pengguna, dan memperbaharui status pemesanan. Customer dapat melihat produk yang dijual, memberikan rating produk, update password, melakukan pemesanan produk, dan melihat status pesanan 


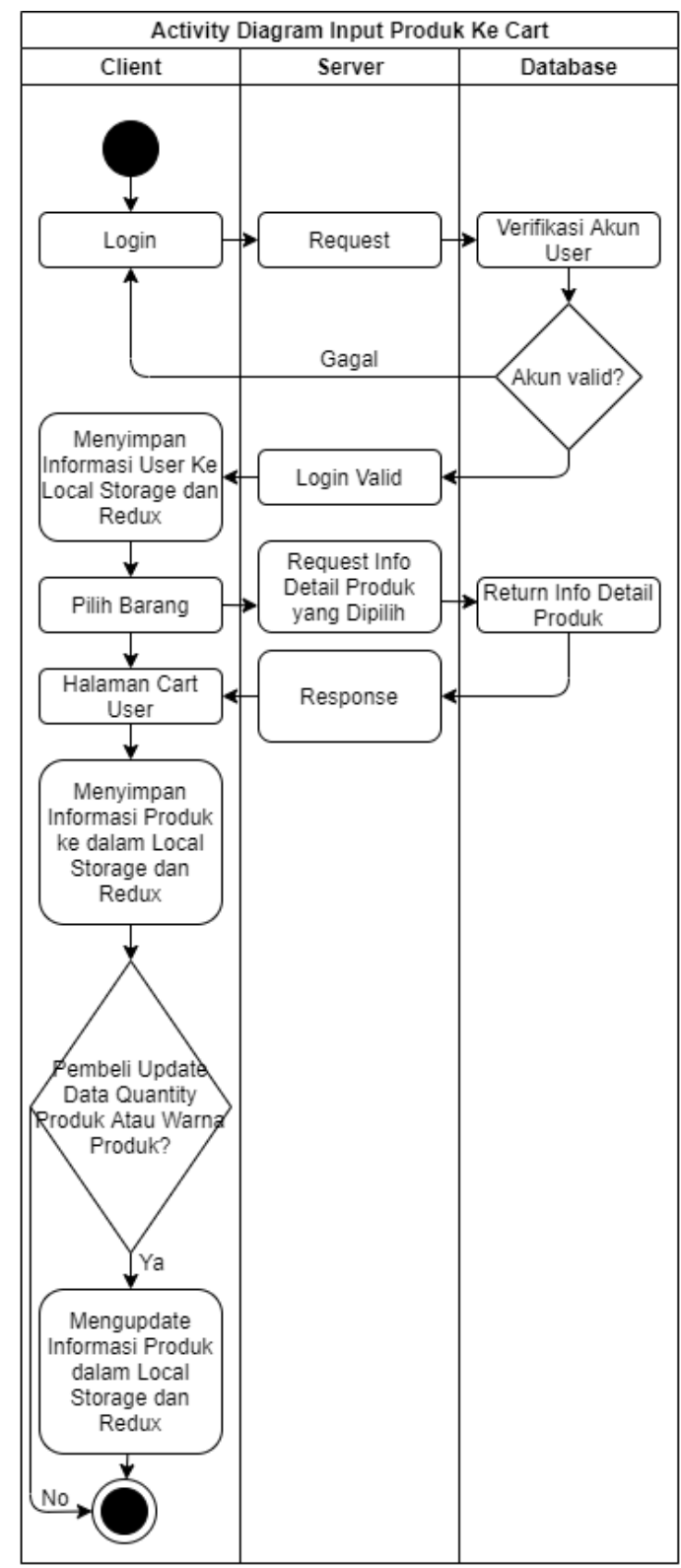

Gambar 4. Activity Diagram Input Produk ke dalam Keranjang

Pada Gambar 4 merupakan activity diagram yang menggambarkan interaksi antara client, server, dan database jika customer memilih barang. Customer login terlebih dahulu, kemudian database akan validasi akun, jika valid maka informasi login user akan disimpan dalam Local Storage dan Redux. Kemudian, jika customer memilih barang maka akan masuk ke halaman cart user dan menampilkan informasi detail produk yang dibeli. Untuk produk yang dimasukkan ke dalam cart secara otomatis juga akan masuk ke dalam Local Storage dan Redux. Redux digunakan untuk menyimpan dan mengelola data antar komponen. Pada halaman cart, customer dapat melakukan update pada setiap produk pada bagian quantity dan warna. 


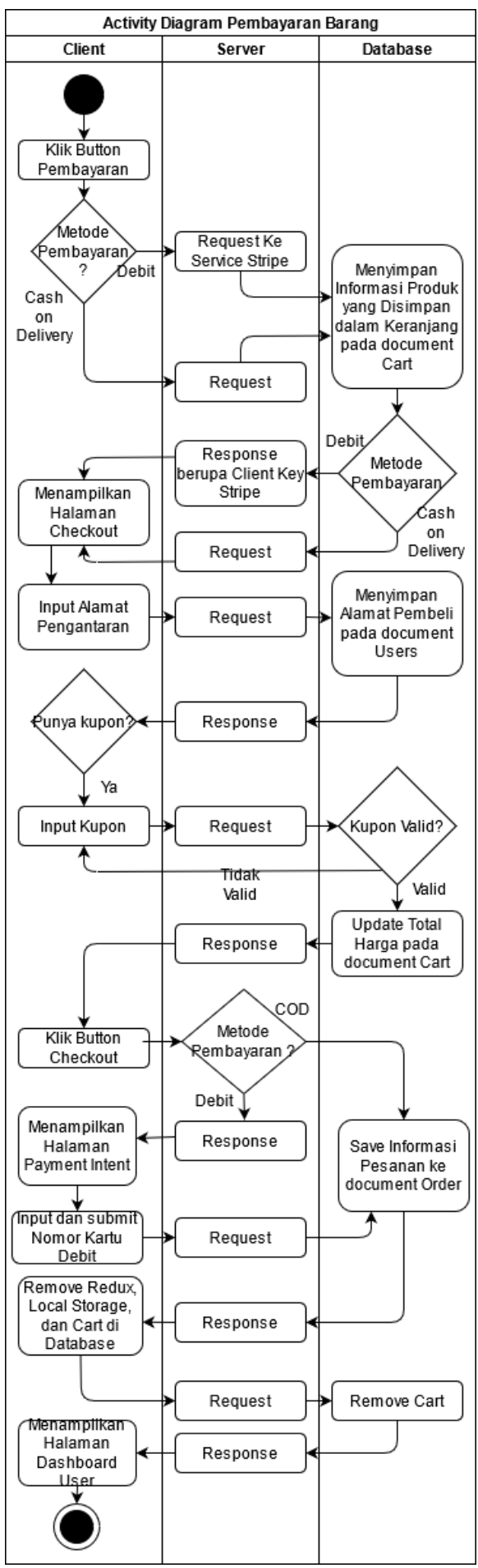

Gambar 5. Activity Diagram Pembayaran

Pada Gambar 5 menunjukkan activity diagram yang menjelaskan interaksi antara client, server, dan database. Pada halaman cart, user dapat memilih metode pembayaran yang diinginkan yaitu metode debit atau cash on delivery. Jika customer memilih metode debit maka akan dilakukan proses request ke service Stripe untuk memperoleh client key, setelah itu customer akan masuk ke halaman checkout, customer dapat menginput alamat dan kupon. Jika kupon yang diinput valid, maka akan langsung update total harga yang harus dibayarkan disesuaikan dengan besar diskon yang terdapat dalam kupon. Setelah itu, customer dapat melanjutkan proses checkout dan akan masuk ke halaman payment intent yang terdapat form input untuk nomor kartu debit. Selanjutnya, customer melakukan submit form dan akan menyimpan informasi order ke 
document Order pada MongoDB. Jika customer memilih metode cash on delivery, maka informasi order akan langsung disimpan ke dalam document Order.

\section{HASIL DAN PEMBAHASAN}

Hasil dan pembahasan meliputi website penjualan produk mebel dengan menerapkan teknologi MongoDB, Express, React, dan Node. js (MERN) yang dapat digunakan sesuai dengan analisis kebutuhan yang telah dilakukan. Website ini berfungsi membantu pemilik toko dalam memasarkan produknya, memudahkan pembeli dalam melakukan pemesanan, dan mendapat informasi terkait status pesanan pembeli.

Pada saat pertama kali mengakses website, customer akan berada pada halaman home yang berisi daftar produk-produk mebel yang dijual. Pada bagian menu navigasi, customer dapat melakukan register dengan memasukkan email dan password dan bagi customer yang sudah memiliki akun dapat login menggunakan email.

Setelah login, customer akan masuk ke halaman dashboard untuk customer. Pada dashboard customer terdapat informasi history pesanan yang dilakukan oleh customer, halaman untuk penggantian password customer, dan halaman untuk menampilkan wishlist produk. Jika login sebagai admin, maka akan masuk ke halaman dashboard untuk admin. Pada dashboard admin terdapat halaman untuk menampilkan informasi pesanan yang masuk, halaman untuk menampilkan daftar produk yang dijual, halaman untuk mengelola produk, halaman untuk mengelola kategori dan sub kategori, dan halaman untuk menambah dan menghapus kupon.

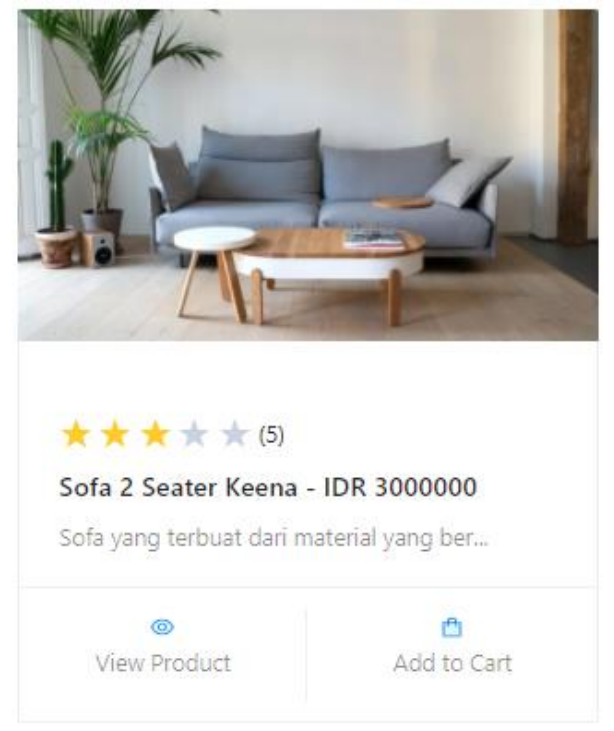

Gambar 6. Komponen Product Card

Pada Gambar 6 adalah komponen product card. Komponen ini berisi informasi produk yang terdiri dari gambar, penilaian, nama, harga, deskripsi, button untuk melihat detail produk, dan button untuk menambahkan produk ke dalam keranjang. Pembeli dapat membeli produk mebel dengan melakukan klik pada button Add to Cart. Setelah itu, pembeli akan diarahkan ke halaman Cart.

Dalam pengembangan front-end, diterapkan konsep reusable component. Penerapan tersebut dapat diketahui dalam komponen product card pada Gambar 6 yang diterapkan pada halaman home dan halaman detail produk. Keuntungan dari penerapan reusable component yaitu kode yang ditulis menjadi lebih singkat sehingga mempercepat pengembangan dikarenakan komponen dapat menerima props atau data dari parent component sehingga produk yang ditampilkan dapat bersifat dinamis. 


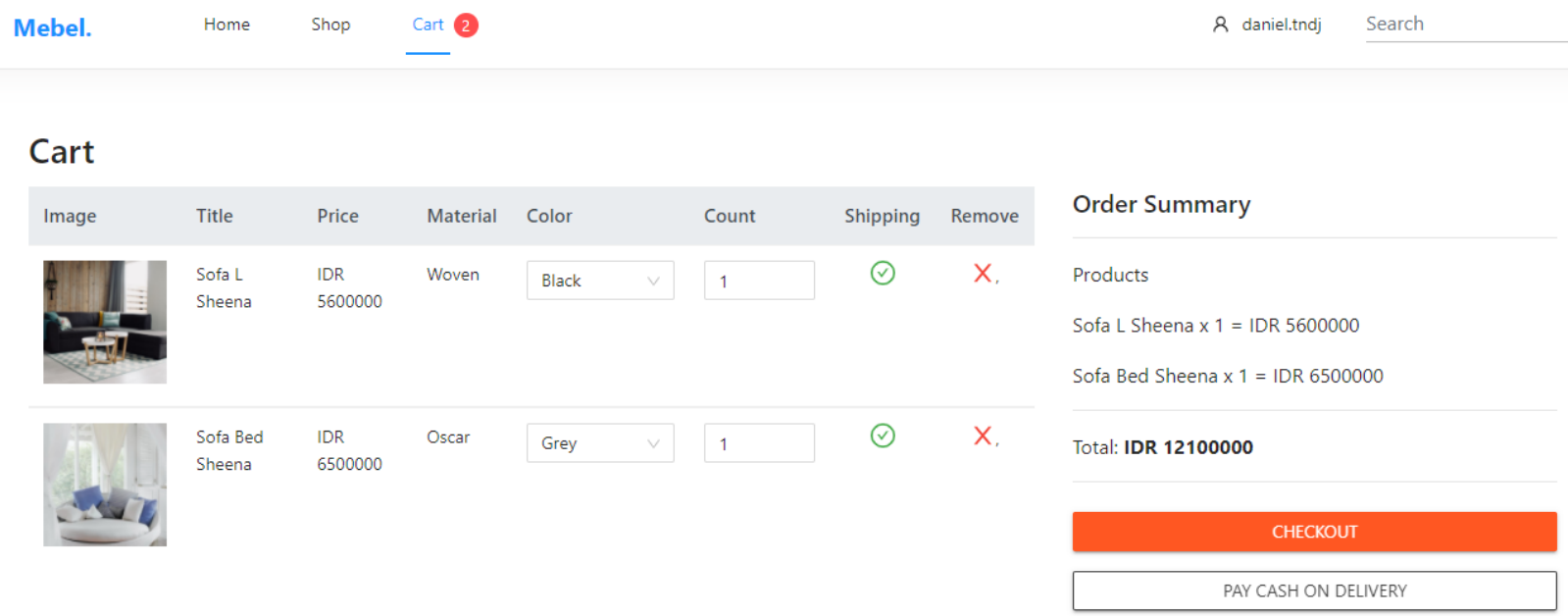

Gambar 7. Halaman Cart

Pada Gambar 7 merupakan halaman Cart, terdapat tabel yang menjelaskan detail produk yang dibeli beserta harga total dari produk. Pembeli dapat memilih metode pembayaran yang tersedia yaitu metode debit atau cash on delivery. Jika pembeli memlih metode debit maka pembeli harus menginput nomor kartu. Setelah memilih metode pembayaran, pembeli akan masuk ke halaman checkout.

Mebel. Home Shop Cart 2

Delivery Address

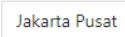

SAVE

Got Coupon?

COUPON

APPLY
8 daniel.tndj Search Q

Gambar 8. Halaman Checkout

Pada Gambar 8, pembeli diwajibkan memasukkan alamat tujuan pengiriman dan pembeli dapat menginput kode kupon jika memilikinya. Setelah menginput, pembeli dapat melakukan proses pembayaran dengan melakukan klik pada button Place Order.

Order Summary

Products (2)

Sofa L Sheena (Black) X $1=5600000$

Sofa Bed Sheena (Grey) X $1=6500000$

Cart Total: IDR 12100000

Total Payment After Discount: IDR 1210000.00

PLACE ORDER (CARD)

EMPTY CART 


\section{Complete Your Purchase}

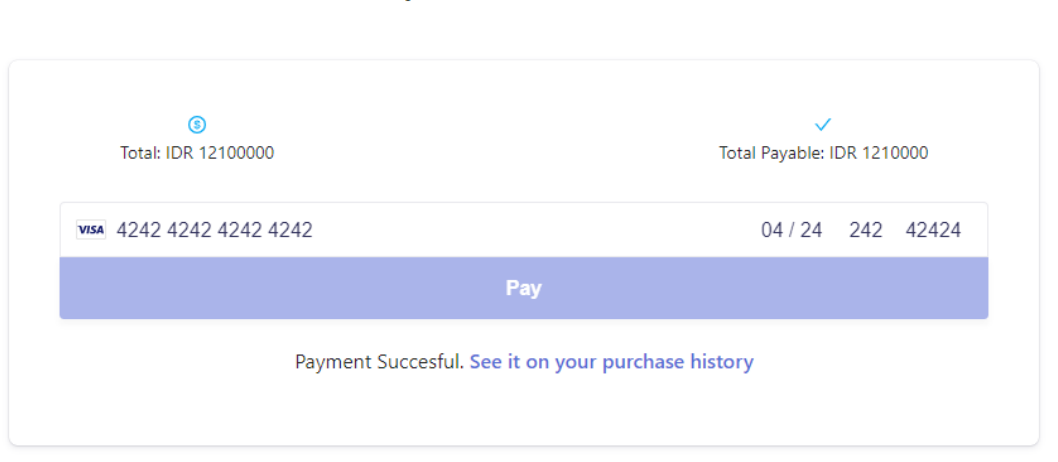

Gambar 9. Halaman Input Nomor Kartu Debit

Setelah itu pada Gambar 9, pembeli menginput nomor kartu untuk melakukan pembayaran dan pembeli akan diarahkan ke halaman dashboard customer.

Setelah melakukan transaksi, admin akan melakukan update status pesanan pada halaman dashboard admin. Status pesanan terdiri diri, antara lain:

1. Not Processed

Jika pembayaran dilakukan dengan metode debit maka status pesanan akan otomatis menjadi Not Processed.

2. Cash on Delivery

Jika pembayaran dilakukan dengan metode debit maka status pesanan akan otomatis menjadi Cash on Delivery.

3. Processing

Jika barang tersedia dan alamat pengantaran berada dalam jangkauan maka status pesan akan diubah menjadi

Processing.

4. Dispatched

Jika barang dalam proses pengiriman menuju alamat pembeli maka status pesan akan diubah menjadi Dispatched.

5. Cancelled

Jika barang yang dipesan tidak tersedia atau alamat pengantaran di luar jangkauan maka status pesanan akan diubah menjadi Cancelled.

6. Completed

Jika barang sudah diterima pembeli maka status pesanan akan diubah menjadi Completed.

Untuk setiap pergantian status pesanan maka secara otomatis akan mengirim notifikasi ke email pembeli yang terdaftar, sehingga pembeli dapat mengetahui status pesanan.

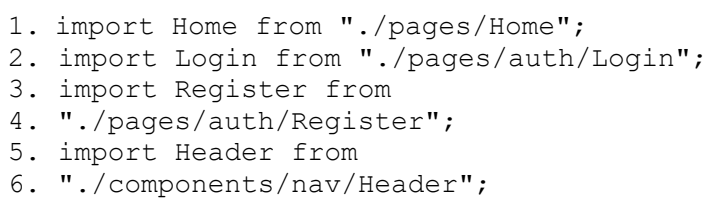

Kode Program 1. Import Komponen Tanpa Menggunakan Code Splitting

Pada Kode Program 1 terdapat kode program yang berfungsi melakukan import komponen tanpa penerapan code splitting. Import merupakan salah satu fitur dari ES2015 Module JavaScript yang digunakan untuk import function, objek, atau variabel yang sudah di export pada modul lain. 


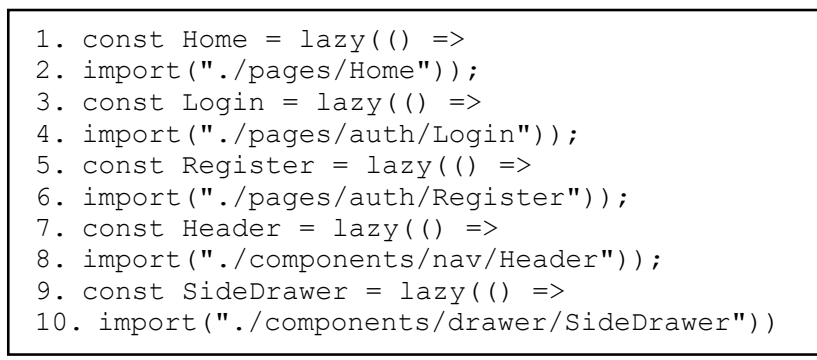

Kode Program 2. Import Komponen dengan Menggunakan Code Splitting

Pada Kode Program 2 terdapat kode program yang berfungsi melakukan import komponen dengan menggunakan function lazy. Lazy berfungsi untuk melakukan render komponen ketika komponen itu dibutuhkan sehingga ketika halaman pertama kali diakses oleh pengguna maka tidak semua komponen akan diproses sehingga akan mengurangi waktu render dari suatu komponen.

Pengujian user interface dilakukan dengan menggunakan fitur React Profiler yang tersedia pada React Dev Tools yang berfungsi menguji waktu rendering komponen pada saat halaman website pertama kali diakses. Pada Tabel 1 menunjukkan hasil rata-rata total waktu yang diperlukan untuk rendering komponent pada client side dalam satuan waktu milisecond antara penerapan code splitting React dan tanpa menggunakan code splitting React. Pada keseluruhan komponen yang terdapat pada halaman website yang diuji menunjukkan pengurangan waktu dalam rendering. Sebelum penerapan code splitting, seluruh komponen akan ditampilkan langsung oleh browser sehingga dibutuhkan waktu yang lebih banyak dibandingkan setelah menerapkan code splitting yang akan render komponen yang dibutuhkan oleh $u$ ser.

TABEL 1

PERBANDINGAN RENDER DURATION KOMPONEN

\begin{tabular}{lcc}
\hline \multirow{2}{*}{ Komponen } & \multicolumn{2}{c}{ Render Duration (milisecond) } \\
\cline { 2 - 3 } & $\begin{array}{c}\text { Tanpa Code } \\
\text { Splitting }\end{array}$ & $\begin{array}{c}\text { Menggunakan } \\
\text { Code Splitting }\end{array}$ \\
\hline Home & 94.4 & 64.3 \\
\hline Shop & 237 & 90.4 \\
\hline Detail Product & 283 & 96.7 \\
\hline Cart & 141 & 97.9 \\
\hline Checkout & 98.3 & 81.2 \\
\hline User Dashboard & 73.4 & 62.1 \\
\hline User Password & 67.7 & 47.3 \\
\hline User Wishlist & 118 & 59.1 \\
\hline $\begin{array}{l}\text { Admin } \\
\text { Dashboard }\end{array}$ & 110.5 & 68.4 \\
\hline $\begin{array}{l}\text { Admin Create } \\
\text { Product }\end{array}$ & 91.1 & 75.9 \\
\hline $\begin{array}{l}\text { Admin Manage } \\
\text { Product }\end{array}$ & 99.2 & 54.3 \\
\hline $\begin{array}{l}\text { Admin Manage } \\
\text { Category }\end{array}$ & 150 & 52.2 \\
\hline $\begin{array}{l}\text { Admin Manage } \\
\text { Sub Category }\end{array}$ & 81.5 & 47.8 \\
\hline $\begin{array}{l}\text { Admin Manage } \\
\text { Coupon }\end{array}$ & 65.8 & 67.28 \\
\hline Rata-rata & 122.20 & \\
\hline & & \\
\hline
\end{tabular}

Pengujian aplikasi dilakukan dengan menguji fungsi-fungsi dari aplikasi yang telah dibuat untuk mencari bug pada sistem. Pengujian aplikasi dilakukan agar sistem yang dibuat berjalan sesuai dengan yang diharapkan dan dapat memenuhi kebutuhan pengguna. Pengujian aplikasi ini menggunakan teknik pengujian yaitu pengujian alpha dan beta. Pengujian 
Alpha adalah pengujian yang dilakukan oleh pihak developer. Tabel 2 adalah hasil pengujian alpha dari aplikasi yang telah dilakukan.

Berdasarkan hasil pengujian alpha yang ditampilkan dalam Tabel 2 menunjukkan masing-masing fungsionalitas dari website penjualan mebel berjalan dengan baik dan sesuai dengan harapan pengguna.

TABEL 2

Hasil Pengujian Alpha

\begin{tabular}{|c|c|c|c|}
\hline $\begin{array}{l}\text { Fungsi yang } \\
\text { Diuji }\end{array}$ & Kondisi & Hasil & $\begin{array}{c}\text { Status } \\
\text { Pengujian }\end{array}$ \\
\hline Register & $\begin{array}{l}\text { Mengirim email ketika } \\
\text { button register diklik }\end{array}$ & $\begin{array}{l}\text { Sukses mendapat email untuk } \\
\text { memasukkan password dan berhasil } \\
\text { memasukkan password }\end{array}$ & Valid \\
\hline Login & $\begin{array}{l}\text { Login menggunakan email } \\
\text { dan Google account }\end{array}$ & Sukses login & Valid \\
\hline Produk & $\begin{array}{l}\text { Admin melakukan Create, } \\
\text { update, dan delete, produk }\end{array}$ & $\begin{array}{l}\text { Sukses create, update, dan delete } \\
\text { produk }\end{array}$ & Valid \\
\hline $\begin{array}{l}\text { Menambah } \\
\text { produk ke cart }\end{array}$ & $\begin{array}{l}\text { Customer dapat } \\
\text { menambahkan satu atau } \\
\text { lebih produk ke dalam } \\
\text { cart }\end{array}$ & $\begin{array}{l}\text { Tidak ada duplikasi produk jika user } \\
\text { sudah menambahkan produk yang } \\
\text { sama sebelumnya }\end{array}$ & Valid \\
\hline $\begin{array}{l}\text { Update produk } \\
\text { pada halaman } \\
\text { cart }\end{array}$ & $\begin{array}{l}\text { Customer dapat } \\
\text { melakukan update } \\
\text { quantity dan warna produk }\end{array}$ & Sukses melakukan update & Valid \\
\hline Pembayaran & $\begin{array}{l}\text { Pembayaran dengan debit } \\
\text { atau cash on delivery }\end{array}$ & $\begin{array}{l}\text { Customer berhasil melakukan } \\
\text { transaksi }\end{array}$ & Valid \\
\hline $\begin{array}{l}\text { Update status } \\
\text { pesanan }\end{array}$ & $\begin{array}{l}\text { Admin dapat melakukan } \\
\text { update status pesanan }\end{array}$ & Status pesanan berhasil diperbaharui & Valid \\
\hline
\end{tabular}

Untuk pengujian beta yang ditunjukkan pada Tabel 3 terdapat kuesioner yang berisi pertanyaan-pertanyaan yang ditujukan untuk memperoleh tanggapan dari responden. Pengguna terlebih dahulu mencoba website kemudian pengguna diminta memberikan tanggapan melalui kuesioner. Kuesioner terdiri dari 5 pertanyaan yang bertujuan untuk mengetahui pendapat pengguna terkait website penjualan Toko Mebel Murah.

TABEL 3

Hasil Pengujian Beta

\begin{tabular}{clccccc}
\hline No & \multicolumn{1}{c}{ Pertanyaan Kuesioner } & STS & TS & N & S & SS \\
\hline 1. & $\begin{array}{l}\text { Apakah website menampilkan konten } \\
\text { informasi di bawah 3 detik saat pertama } \\
\text { kali diakses? }\end{array}$ & 0 & 0 & 2 & 9 & 9 \\
2. & $\begin{array}{l}\text { Apakah website dapat mempermudah } \\
\text { dalam pemesanan produk mebel? }\end{array}$ & 0 & 1 & 1 & 8 & 10 \\
\hline 3. & $\begin{array}{l}\text { Apakah website dapat memberikan } \\
\text { informasi dari setiap produk mebel? }\end{array}$ & 0 & 0 & 4 & 8 & 8 \\
\hline 4. & $\begin{array}{l}\text { Apakah dengan website ini } \\
\text { mempermudah dalam tracking status } \\
\text { pesanan? }\end{array}$ & 0 & 1 & 7 & 7 & 5 \\
\hline 5. & $\begin{array}{l}\text { Apakah tampilan website mudah } \\
\text { dipahami? }\end{array}$ & 0 & 0 & 1 & 10 & 9 \\
\hline
\end{tabular}

Jumlah responden yang terlibat dalam pengisian kuesioner adalah 20 orang yang terdiri dari pemilik dan karyawan dari toko Mebel Murah dan customer. Untuk menghitung indeks dari setiap jawaban kuesioner maka digunakan skala Likert [13]. Pada Tabel 4 menunjukkan jawaban dari kuesioner yang terdiri atas 5 variasi dan masing-masing diberi nilai. 
TABEL 4

PENILAIAN BERDASARKAN JAWABAN

\begin{tabular}{lc}
\hline \multicolumn{1}{c}{ Jawaban } & Nilai \\
\hline $\begin{array}{l}\text { Sangat Tidak Setuju } \\
\text { (STS) }\end{array}$ & 1 \\
\hline Tidak Setuju (TS) & 2 \\
\hline Netral (N) & 3 \\
\hline Setuju (S) & 4 \\
\hline Sangat Setuju (SS) & 5 \\
\hline
\end{tabular}

Untuk mengetahui indeks dari setiap jawaban maka dilakukan perhitungan dengan menggunakan rumus 1:

Indeks $(\%)=\frac{\text { Total Nilai }}{\text { Jumlah Responden } \times \text { Nilai Maksimum }} \times 100 \%$

Untuk menyimpulkan hasil perhitungan skala Likert maka dapat dilakukan dengan analisis interval nilai. interval nilai dihitung dengan menggunakan rumus 2 :

Interval Nilai $=\frac{\text { Jumlah Responden }}{\text { Jumlah Nilai }}$

Berdasarkan rumus 1 dan rumus 2 maka kriteria interval nilai dapat ditunjukkan pada Tabel 5.

TABEL 5

INTERVAL PENILAIAN INDEKS

\begin{tabular}{ll}
\hline \multicolumn{1}{c}{ Interval Nilai } & \multicolumn{1}{c}{ Kategori } \\
\hline Indeks 0\% - 19,99\% & $\begin{array}{l}\text { Sangat Tidak Setuju } \\
\text { (STS) }\end{array}$ \\
\hline Indeks 20\% $-\mathbf{3 9 , 9 9 \%}$ & Tidak Setuju (TS) \\
\hline Indeks 40\% $-\mathbf{5 9 , 9 9 \%}$ & Netral (N) \\
\hline Indeks 60\% $-\mathbf{7 9 , 9 9 \%}$ & Setuju (S) \\
\hline Indeks 80\% - 100\% & Sangat Setuju (SS) \\
\hline
\end{tabular}

Dari Tabel 6 menunjukkan hasil perhitungan indeks dari masing-masing pertanyaan kuesioner. Dari pertanyaan 1 dapat disimpulkan bahwa website dapat menampilkan informasi secara cepat di sisi klien karena sudah memanfaatkan fitur code splitting. Dari pertanyaan 2 dapat disimpulkan bahwa website dapat mempermudah pembeli dalam memesan produk mebel. Dari pertanyaan 3 dapat disimpulkan bahwa website ini dapat memberikan informasi yang jelas terhadap pembeli terkait informasi produk mebel yang dijual. Dari pertanyaan 4 dapat disimpulkan bahwa pembeli dapat mendapatkan informasi terkait status pesanan melalui email. Dari pertanyaan 5 dapat disimpulkan bahwa user interface website mudah dimengerti oleh pengguna.

TABEL 6

HASIL PERHITUNGAN INDEKS

\begin{tabular}{cccl}
\hline Pertanyaan & $\begin{array}{c}\text { Total } \\
\text { Nilai }\end{array}$ & Indeks & \multicolumn{1}{c}{ Kategori } \\
\hline 1. & 87 & $87 \%$ & Sangat Setuju (SS) \\
\hline 2. & 87 & $87 \%$ & Sangat Setuju (SS) \\
\hline 3. & 84 & $84 \%$ & Sangat Setuju (SS) \\
\hline 4. & 76 & $76 \%$ & Setuju (S) \\
\hline 5. & 88 & $88 \%$ & Sangat Setuju (SS) \\
\hline
\end{tabular}




\section{SIMPULAN}

Berdasarkan penelitian dan pembahasan di atas maka dapat ditarik simpulan bahwa pengembangan front-end dari sistem penjualan produk mebel dapat menerapkan konsep reusable component untuk menghindari pengulangan kode sehingga dapat mempercepat pengembangan website serta kode yang dihasilkan menjadi lebih terstruktur dan mudah dalam pengembangan ke depannya. Dalam mempersingkat waktu rendering di sisi klien dapat disimpulkan bahwa dengan menggunakan strategi code splitting yang terbukti efektif berdasarkan dari hasil pengujian yang dilakukan dengan menggunakan React Profiler.

Berdasarkan tahapan penelitian yang telah dilakukan maka dapat disimpulkan juga bahwa website ini memiliki fungsionalitas yang baik dimana pembeli dapat dipermudah dalam melakukan pembelian produk mebel secara online dan membantu pembeli dalam mengetahui status pesanan melalui notifikasi email. Saran untuk pengembangan penelitian ini pada masa yang akan datang adalah melalukan unit testing pada kode dalam komponen React yang sudah dibuat untuk memastikan bahwa kode tersebut berjalan sesuai dengan harapan dan fitur chat dalam website yang membantu admin dan pembeli dalam berkomunikasi secara langsung.

\section{DAFTAR PUSTAKA}

[1] M. Bajammal, D. Mazinanian, and A. Mesbah, "Generating reusable web components from mockups," ASE 2018 - Proc. 33 rd ACM/IEEE Int. Conf. Autom. Softw. Eng., pp. 601-611, 2018, doi: 10.1145/3238147.3238194.

[2] Christopher. (2020). How To Maximize Reusability For Your React Components. [Online]. Available: https://jsmanifest.com/how-to-maximizereusability-for-your-React-components/.

[3] H. Nguyen, "End-to-end E-commerce web application, a modern approach using MERN stack," no. May, 2020.

[4] G. Kivilohkare, "Optimizing the Critical Rendering Path for Decreased Website Loading Time," 2020.

[5] A. Bhalla, S. Garg, and P. Singh, "Present Day Web-Development Using Reactjs,” no. May, pp. 1154-1157, 2020.

[6] P. Speed, "Mobile-Page-Speed-New-Industry-Benchmarks," no. February, 2017.

[7] Facebook. (2020). A JavaScript library for building user interfaces. [Online]. Available: https://Reactjs.org/.

[8] E. Wohlgethan, "Bachelorarbeit Comparing Three Major JavaScript Frameworks :," 2018.

[9] Facebook, (2020). Components and Props. [Online]. Available: https://Reactjs.org/docs/components-and-props.html.

[10] A. Kumar and R. K. Singh, “Comparative analysis of angularjs and Reactjs,” Int. J. Latest Trends Eng. Technol., vol. 7, no. 4, pp. 225-227, 2016, doi: $10.21172 / 1.74 .030$.

[11] Facebook. (2020). Code Splitting. [Online]. Available: https://id.Reactjs.org/docs/code-splitting.html.

[12] Hanafi, “Konsep Penelitian R \& D Dalam Bidang Pendidikan,” Saintifika Islam. J. Kaji. Keislam., vol. 4, no. 2, pp. $129-150,2017$.

[13] T. Nempung, T. Setiyaningsih, and N. Syamsiah, "Otomatisasi Metode Penelitian Skala Likert Berbasis Web,” no. November, pp. 1-8, 2015. 